\title{
Challenging the New Order's Communist Figures: A New Historicism Study on Penjagal Itu Telah Mati
}

\author{
Muhammad Taufiqurrohman \\ Faculty of Humanities, Universitas Jenderal Soedirman, Indonesia \\ Email: muhammad.taufiqurrohman@unsoed.ac.id
}

\begin{abstract}
This paper aims to discuss the images of communist figures in Post-Suharto 1965 fictional narratives. Images of communists or alleged-communists appeared in many books and films produced under the Suharto regime as villains and atheists, antagonists of the nation who deserved to be jailed and killed. This paper, applying the descriptive-qualitative method and new historicism as theoretical framework, unpacks these infamous, stereotypical images of communists and alleged-communists and juxtaposes them with their counterparts in Post-Suharto 1965 fictional narratives. The end of the Suharto regime, which brought freedom of speech, enabled some victims of post-1965 tragedy (mostly ex-political prisoners) and their descendants to articulate a counter-culture and write other version of historiography. One of these authors is Gunawan Budi Susanto, who wrote a 1965 short story collection titled Penjagal Itu Telah Mati (The Slaughterer Has Died) (2015). Susanto's stories challenge New Order's images of communist or alleged-communist figures, depicting most of them as good citizens. While images of communist figures are not as stable and absolute as what the New Order constructed, they remain contested in the unfinished historiography.
\end{abstract}

Keywords: communist figures; images; '65 book; new historicism

\section{INTRODUCTION}

This paper analyses one Penjagal Itu Telah Mati (The Slaughterer Has Died), a collection of short post-Suharto 1965 fictional narratives by Gunawan Budi Susanto. The term "Post-Suharto 1965 fictional narrative" denotes stories about the 1965 tragedy published after the fall of the New Order's regime. The decline of the New Order has brought freedom of speech for Indonesian people to publically discuss some taboo aspects of national history. The 1965 1966 tragedy is the best evidence. From its beginning, the Suharto regime paid special attention to this tragedy and the construction of an official historiography around it. According to this official historiography, 1965-1966 was a result of PKI's coup. This monolithic historiography was disseminated for fifty years via radiobroadcasting, military magazines, films, caricatures, and literary works. As a result, Indonesian people commonly accept that millions of communists or alleged-communists deserved to be jailed and slaughtered. Soon after Suharto's political exit, however, many Indonesian authors began producing new narratives, especially literary works, that challenged the official historiography. Generally, these works try to provide other version of national historiography dealing with the 1965 tragedy.

Researchers have already conducted analysis on many of these narratives. Kiswondo (2006, quoted in Yoseph Yaphi Thaum's thesis) analysed 5 novels and 4 short stories published in the first decade of the postSuharto era (1997-2005). Most of these fictional narratives are written by ex-political prisoners detained for their alleged roles in the 1965 coup. The five novels are Merajut Harkat, by Putu Oka Sukanta, 1999; Tapol, by Ngarto Februana, 2000; Layang-layang Itu Tak Lagi Mengepak Tinggi-tinggi, by Martin Alaeda, 2003; Derak-derak by Zoya Herawati, 2005, and Kemerdekaan Dimulai dari 
Lidah, by A.D. Donggo, 2005; and the four short stories are Tailalat by Pramoedya Ananta Toer, 1997; Perjalanan Pengantin by G.M.Sudarta, 2003; Gerbang (Bukan Surga Bukan Neraka) by Koeslan Budiman, 2004; and Menunggu Telinga Tumbuh by Indra Tranggono, 2005. Although Kiswondo's analysis has some weaknesses, the analysis at least opened a discussion in the new territory of post-Suharto 1965 fiction studies.

In the second decade of post reformation, there many fictional narratives emerged that feature the 1965 tragedy as the background. Two of them received national attention. They are Amba, by Laksmi Pamuntjak, 2012; and Pulang, by Leila S. Chudlori, 2012. Amba tells about a story of the protagonist Amba's life and her love affair with Bhisma, a Leipzig-graduate doctor who sympathizes with leftist movement in 1965 Indonesia. Pulang explores similar themes, but is set in Paris and Jakarta. This narrative follows Lintang Utara, a daughter of Dimas Suryo, an Indonesian political exile in France, and Vivienne Deveraux, a student who became involved in demonstrations against French government. After 1965, Dimas and his friends, Nugroho, Tjai and Risjaf, who were on an overseas journey, could not return to Indonesia. They were considered leftist intellectuals and banned by the New Order.

In both literary studies and history, Jakarta-based authors with established national and international audiences tend to receive more attention than their more marginal counterparts. As Anthony Reid (2016:7) notes, for example, the traditional historiography has been constructed mainly by authors like UI's Nugroho Notosusanto, who lived at the political center, Jakarta, and sympathized with the Army and its national project. Nugroho favored the Army which was in power after 1966 and "gave the military the kind of history they wanted," and eclipsed more marginal and subversive authors like UGM's Sartono Kartodirdjo. Producing this historiography led to Nugroho's being appointed Minister of Education and Rector of UI (1983-86). Reid also states that Jogja historians knew about Sartono's critique of Nugroho's version of the 1965 event in Volume 6 of Sejarah Nasional Indonesia. Unlike Nugroho, Sartono who located far from Jakarta, both politically and geographically, and remained distant from the politics. As a result, Nugroho's version of 1965 became the dominant historiography in Indonesia and has maintained its centrality to this day.

Responding to this phenomenon, I offer an analysis of works of a less nationally recognized author, Gunawan Budi Susanto. Susanto, living in Semarang, has already published three short story collections,
Nyanyian Penggali Kubur (Song of Tomb Digger) (2011 - one year prior to Amba and Pulang), Penjagal Itu Telah Mati (The Slaughterer Has Died) (2015), and Cik Hua (2018). Published by local publishers (Gigih Media in Semarang and Pataba in Blora), these three collections contain stories rooted in the author's personal experience as the son of a father murdered in the 1965 tragedy. This paper argues that Penjagal Itu Telah Mati (The Slaughterer Has Died) embodies counter-images that challenge the New Order's 1965 historiography, particularly regarding communists and their affiliates. In short, this paper seeks to contextualize and make sense of the images of communist or alleged-communist figures depicted in Susanto's short stories.

\section{METHODOLOGY}

This descriptive-qualitative research mainly applies the "thick description" or "in-depth reading" method, wherein the researcher observes the same text repeatedly in pursuit of comprehensive meaning (Geertz, 1973: 25). After articulating the "always-unfinished-meaning," the researcher puts it into the discursive and historical context using secondary data such as historical books, journals, magazines, and films as well. Both fiction and nonfiction are examined to produce new meanings beyond the texts themselves.

This paper applies New Historicism as the main theoretical lens. This framework assumes that historical phenomena can be read like texts, or vice versa. In other words, any text, including literary texts, can be read like historical texts. H. Aram Veeser has isolated five key assumptions foundational to New Historicism (Castle, 2007, 132): 1) "Every expressive act is embedded in a network of material practices"; 2) Every critique inevitably "uses the tools it condemns and risks falling prey to the practice it exposes"; 3) Literary and nonliterary texts "circulate inseparably"; 4) No discourse "gives access to unchanging truths" nor "expresses inalterable human nature"; and 5) Critical methods under capitalism "participate in the economy they describe." The theory postulates that literary and non-literary texts are inseparable. Every text has its own formation and ideology, and there is no stable and absolutely true discourse within any text, including literature ones. This theoretical framework is used to build the analysis by linking the stories of the collection with the world outside it, especially the life of the author, the historical context of the 1965 tragedy, and the socio-political context of his emergence as an author.

With these five key assumptions, this article 
1) reveals how "the collection as an expressive act is embedded in a network of material practices" by showing the relation between the stories, the biography of the author, and the socio-historical context of the work; 2) shows how both the literary and non-literary texts "circulate inseparably" by comparing and contrasting the content of the stories with the historical books, journals, magazines, and films that have depicted the 1965 tragedy; and 3) shows that the official historiography of the 1965 tragedy, and more specifically the representation of communist and alleged-communist figures in that historiography, though deeply entrenched in the Indonesian scholarly and popular discourses, is "not [the] stable and unchanging truth" that the Suharto regime attempted to construct.

\section{FINDINGS AND DISCUSSION}

This analysis of Susanto's works aims to uncover different first-hand images of communist figures that undermine the New Order's hegemonic discourse. The findings hopefully provide alternative discourses of 1965 tragedy. At the very least, this paper seeks to unearth the fact that images of communists and alleged communists are not as stable and absolute as many Indonesians tend to believe.

\section{The Collection is Embedded in a Network of Material Practices}

The collection Penjagal Itu Telah Mati is embedded in a network of historical events. Two historical facts in particular seem especially relevant to any analysis of the collection. First, Susanto's family background as the son of PKI-alleged father and then-Gerwani mother may be understood as an exigence for the production of the stories. His father was a teacher and communist and was one of the 1965 victims who disappeared and remains unfound. This family tragedy and Susanto's memory of it greatly influence his works.

In his memoir Metamorfosis Keterpelajaran (Metamorphosis of Educatedness) (2015:xx), Susanto recalls that being a son of a late PKI affiliate father and a then-Gerwani mother was a sin in the eye of his neighbors. Peers and neighbors often bullied him and assailed him with taunts like, "What a mischievous boy! PKI-Gerwani boy!" The only way Susanto could defend his self-dignity was physical violence. Thus, fighting became a ritual. This eventually led Susanto to withdraw from society. He preferred to live all by himself in his room, reading any books by Anny Arrow, Nick Carter, Kho Ping Hoo, Gan K.L. and S.H.Mintardja.

Second, Susanto's position as an anti-New Order activist also affects his stories in the collection. As an anti-Suharto activist, he strongly criticized the New Order's policies, be they social, political, or cultural. In 1982 Susanto started to study Indonesian Literature at Diponegoro University. The 1980s were a time of socalled "normalization of campus life," which meant, in practice, that students were widely discouraged from political engagement. This idea of normalization was a reaction to earlier campus-based political activities, such as the Golongan Putih Movement, initiated by Arief Budiman (a lecturer of UKSW Salatiga) and friends in 1977, the event of January 15th of Harimen Siregar (a student leader of UI) and friends, and the anti-China riot in 1980.

As a student, Susanto was very disappointed with campus academic life. There was no freedom of speech at the university, and the government banned so-called "leftist books" like Pramoedya Ananta Toer's tetralogy. Any students who were found reading these forbidden books were considered to be breaking the law. Under the New Order regime, Susanto preferred to engage with people and communities outside university. In this period, he had to play hide and seek with police and soldiers. He started to write clandestinely: poems, short stories, pamphlets, and bulletins. All of these writings were finally compiled in the form of a book titled Kesaksian Kluprut (Kluprut's Witness) (Yayasan Sastra Merdeka, 1996).

The cultural policy that Susanto criticized most strongly was the New Order's official historiography of the 1965 event and the subsequent massacre of PKI affiliates. The Indonesian government under Suharto propagated images of communist figures as evil and inhumane. Through many kinds of media, the regime constructed an image of alleged-communist figures as antagonists of the nation who deserved to be imprisoned and slaughtered. In the 1980s, Suharto's New Order seemed obsessed with officially publicizing the "1965 coup story" through cultural arts like film and literature. In 1984, the Suharto regime produced the film Pengkhiatan $G 30 \mathrm{~S} / \mathrm{PKI}$, which officially promotes the legitimacy of Suharto military government. A draft of the script was initially written in 1980 by the New Order historian Nugroho Notosusanto, with full support from his colleague, General G. Dwipayana, a spokesman and private assistant of President Suharto. This film was directed by a legendary Indonesian director, Arifin C. Noer. In 1983, the President signed off on the content of the film. Finally, in 1984, the film was officially released. TVRI, the only official government TV station, broadcasted the film annually on September 30 from 1984 to 1997 . This film was designed to advance a doctrine 
that PKI and its affiliates were the sole actors in the 1965 coup, and more generally to establish the legitimacy of the New Order regime with Suharto as ruler (Herlambang, 2013:163-166).

The military regime also exploits its influence over civil society to spread officially sanctioned narratives about the 1965 coup. One conventional method is granting awards to any works of arts or literature that endorse the ideology of the regime. Ahmad Tohari's novel, Kubah, is a prime example. Awarded "The Best Novel of 1981" by the regime, this text reiterates the New Order's narratives about communist figures. Taufiqurrohman (2015) finds that all communist figures in Kubah-Margo, the tricky teacher cum activist; Suti, the "wild" Gerwani activist; Tan Oen Sok, the greedy Chinese businessman; and Tan Lio Pek's daughter and Oey Fen May, the erotic dancersare all represented as evil and inhumane. The ultimate message of the novel seems to be that all communists and affiliates share these corrupt and immoral characteristics. Kubah is just one of numerous examples of texts that propagate the dominant discourse of New Order.

After the decline of the New Order, Susanto began to openly challenge the New Order's official narrative about 1965 . He started to talk publically about what happened to his family in 1965 and to publicly criticize the official historiography. He also started writing fictional stories about the events of 1965 that, along with his essays and talks, challenged the official historiography. Through the networks that he had cultivated as a senior journalist and writer, he was able to distribute his writings and talks to readers and listeners, especially artists and intellectuals in Central Java. Susanto's stories, both fictional and otherwise, became his most effective weapons against the New Order's legacy.

\section{The Collection and Non-Literary Texts outside "Circulate Inseparably"}

In this section, I seek to link the literary text Penjagal Itu Telah Mati to external, non-literary texts. Three kinds of "outside texts" that are "circulate inseparably" with the stories of the collection: 1) Susanto's non-fictional texts, i.e. his collection of essays Edan-edan di Zaman Edan; 2) Other writers' fictional narratives, including Ahmad Tohari's Kubah; and 3) Other writer's non-fiction, like Ariel Heryanto's State Terrorism, Wijaya Herlambang's Kekerasan Budaya Pasca 65, Ita F, Nadia's Suara Perempuan Korban 65, and other related sources.

At least three communist or alleged-communist characters in Susanto's stories differ significantly from the images promoted by the New Order. Cultural media produced with the full support of the New Order, including films, novels, and history book, as well as cultural products that support the New Order's historiography without direct financial support from New Order, have constructed very negative images of communists and alleged-communists and propagated the following stereotypes: 1) that communist or alleged-communist woman activist, especially Gerwani activists, are wild and sadistic, as exemplified by the Gerwani activist in the film Pengkhianatan; 2) that communist or allegedcommunist teachers are atheists, like Margo in Kubah; and 3) that communist or communist-affiliate artists are immoral and erotic, like Tan Liong Pek and Oey Fen May in Kubah. Susanto seems to have crafted his narrative in direct response to these stereotypes, for the three main characters in his stories are 1) a dedicated woman activist; 2) an idealist teacher, and 3) a dedicated artist.

\section{Ibu (Mother): A Dedicated Woman Activist}

Ibu (mother) is a central figure in most of Susanto's short stories. She is described as a survivor of the 1965 tragedy who was jailed and whose husband was killed without a trial. As a victim, the mother remains silent. She never says a word about the tragedy she experienced in the past. It makes the son, another recurring character, frustrated, for he badly wants to understand what happened to his mother and their family. Despite the mother's continuing silence, the son keeps making efforts to encourage her to talk. Susanto's short stories follow the son's intellectual and emotional journey to uncover what happened to his family in 1965 . He tries to find information about the family tragedy from many second-hand sources, including his parents' former neighbors, relatives, and colleagues. Through this process, he unearths images of his mother as a Gerwani (Indonesian Women Movement) activist that differ markedly from those constructed in popular sources such as "Film Pengkhianatan G30S/PKI," a film that he watched annually when grew up as a teenager.

This seems to reinforce Heryanto's argument (2006:9) that the film Pengkhianatan G30S/PKI has a twofold message. First, the film portrays the Indonesian Communist Party (PKI) as the mastermind of G30S/PKI, justifying the military's following efforts to eradicate the party and its supporters. Second, the film also presents the military's attacks on the PKI as a spontaneous, heroic, and interest-free initiative to rescue the nation-state not only from a potential communist take-over, but also from chaos, terror, and social disintegration. The film has made a substantial end enduring impact on Indonesian society. To this day, most Indonesians accept the film's version of events and tend to stigmatize survivors of communist movements and their affiliates, including the Gerwani 
activists, and their descendents as villains and threats to society.

"Akhirnya Om Bandrio Pun Bicara" ("Om Bandrio Opens His Mouth at Last") reveals the impact that this indoctrination campaign and the resultant social dynamics have had on Gerwani women and their families. The narrator recalls how he and two of his brothers, all sons of a former Gerwani activist, experienced very unhappy childhoods. They were frequently mistreated and bullied PKI children and suffered exclusion from their community. The situation became even worse when they went school, where, for their history classes, they had to watch the film Pengkhianatan, which only further reinforced their ostracization.

The popular discourses in which the brothers are immersed portray the PKI and their affiliates as traitors and slanderers of religion and God. Moreover, Gerwani women are portrayed as disgusting and obscene, dancing in the nude while stabbing generals' bodies. The teenage boys become convinced that their mother committed similar acts. Disgusted and ashamed, the brothers grow rebellious, always disputing their mother's instructions, treating her with contempt and even hatred (Susanto, 2015:97-98).

Even though the brothers do not know precisely who their parents were, their shame, fueled by popular narratives about communists and their affiliates, only intensifies as they grow older. When Om Bandrio applies to be a Pegawai Negeri Sipil (Indonesian Public Servant), he leaves blank all the columns about his father and mother because he fears that if he fills them in, he will be disqualified under the so-called "Bersih Diri" (Clean-Self) and "Bersih Lingkungan" (CleanEnvironment) campaigns (Susanto, 2015:99). These policies required that all citizens applying to work as pubic servants be screened and that ex-political prisoners and their descendants be excluded from the process. In leaving these sections of the application form blank, the Om Bandrio seems to align himself with the New Order instead of his own socially ostracized family.

Om Bandrio lets 50 years pass in silence, keeping the family secret even from his wife and daughter, but one day he finally tells them about this traumatic experience. He recalls the day he spent in jail with his mother, watching an officer tortured and verbally abuse her. A soldier hit him when he cried, scaring him into silence.

This story reveals the effects that stigmatization has on communist or alleged communist figures and their families. Narratives about communists, and especially Gerwani activists like Bandrio's mother, depict them as immoral, evil, and and atheistic, and these narratives are often accepted uncritically by whole communities, and even by the subjects' own descendants. Like Om Bandrio and his brothers, many dissidents' family members internalize this stigma even when they know little of their relatives' past besides what that they learned from New Order propaganda film and books.

However, two models exist for processing and responding to social stigmatization. Om Bandrio represents the first type. As the son of an alleged communist, he keeps his identity secret for almost 50 years - over a decade after Suharto's political exit in 1998. He lacks bravery and is unwilling to show his true identity to the public, or even to his wife and daughter. He studied at the university, earned a bachelor's degree, and became a public servant without ever asking what really happened to his mother and late father in 1965. He thinks that investigating his parents' history would put his own life, career, and family in danger. For a descendant like Bandrio, silence seems like the only option.

The second is exemplified by Om Gun, Om Bandrio's older brother, who, instead of remaining silent, published a collection of short stories about their family's experience of the 1965 tragedy and its aftermath. Quoting Gun's statement, the narrator says that the aim of writing the book was to uncover the truth of their family history instead of continuing to deceive their children. Om Gun hoped that the book could help relieve the burden of the past by revealing what really happened and encouraging them to reconcile with their history. For Om Gun and others like him, stigmatization can be countered through the propagation of more positive narratives. Om Gun's book, for example, promotes more humanized images of his mother and other alleged communist figures and Gerwani women.

In "Ibu Terus-menerus Bungkam" ("Mother Keeps Silent"), Susanto, like Om Gun, presents an alternate image of communist women. The story begins with the words "Ibu [mom] keeps silent." The narrator's mother can easily describe many events from her life, but none from the 1960s and 1970s. One day, Ibu describes her childhood in Blora. She says that she was born in Juwana, the third child after two older brothers, and shared experiences with many other small children there, living under Japanese occupation. In 1954, she graduated from the School of Teacher Education and started teaching in an elementary school in Padangan, east of Cepu. Between Padangan in East Java and Cepu in Central Java, Bengawan Solo River flows. Ibu also talks about pursuing higher education in the School of Advanced Teacher Education. While teaching, she was constantly shuttling back and forth between Cepu and 
Bojonegoro, the neighboring regency, and the commute destroyed her health. She got sick and soon was fired from her job. When she recovered, she married Bapak, another teacher in the same school. Ibu is clearly portrayed as a very dedicated teacher.

In 1957, their first daughter was born, followed by another daughter in 1959, and by a third child, the narrator himself, in 1961. The narrator's younger brother was born in 1963. In 1965, when their mother was arrested and jailed, she was pregnant with her fifth child (Susanto, 2015:15). In addition to being a dedicated teacher, Ibu is also an idealistic activist who often took her son, the narrator, with her to demostrations. He remembers his mother and several other young women marching along the road of the city and yelling, then stopping burning a big paper-based sclupture whom he later realizes was the Malaysian Prime Minister Tengku Abdul Rahman. This long march criticizing the Malaysian government's policy demonstrated Gerwani support for President Sukarno's policy regarding political confrontations against Malaysia and represents Ibu as a courageous woman committed to her ideals. She also frequently took her son with her when she and her friends volunteered to teach peasants and labors to read, even though she was no longer officially a teacher (Susanto, 2015:16). Here, Ibu's identities as Gerwani activist and dedicated teacher converge, and the story depicts her, in no uncertain terms, as a woman invested in promoting social welfare and improving the working class's education. Of course, these images pose a serious threat to the New Order's propaganda.

Ibu appears in other stories in the collections as well, where more details about her are revealed. In "Aku Belum Tahu Dimana Kubur Bapak" ("I Have No Idea Where My Father's Tomb Is"), Ibu's handwriting is praised. She writes stories about her childhood and more recent experiences, even though few women of her generation were literate, and but when it comes to writing about the 1965 tragedy, her ability to narrate disappears.

Ibu also appears in "Tamu dari Masa Lalu" ("A Guest from the Past"). In this story, Hendrawan Soekotjo, an old man, visits the narrator's house to tell him a story. He explains that he was a friend of the narrator's late father when they were in jail. Before being executed, the narrator's father insisted that three pieces of information be passed along to his oldest son, i.e. the narrator: first, that he chose to be executed to in place of his wife, whom the military had sentenced to execution, so that she could survive and continue caring for their children; second, that he supported his wife, the narrator's mother, when she joined the Gerwani movement, and that he was very proud of her; and third, that his father and mother were indisputably innocent and had been unjustly jailed. In other words, they became political detainees without trial. Like the two previous stories, "A Guest From the Past" reinforces the image of Ibu as a dedicated teacher and Gerwani activist willing to make sacrifices for the good of her family and the community at large.

In "Penembang Malam" ("Night Singer"), Susanto further develops Ibu's characterization, describing her as a primadona in the circle of educated people in town. Her engagement with the community is evidenced by her social activities, primarily teaching and training. Being an educator with the specific skills needed to teach reading, writing, counting, embroidering, sewing, and bamboo plaiting distinguishes her since most Indonesian people at that time were illiterate. This story also tells how Ibu and her late husband kept teaching informal classes without any payment, demonstrating their selflessness and commitment to the betterment of the community (Susanto, 2015:76). This image of a communist woman as kind and integrated into her community is further developed in another story entitled "Percakapan Kakek dan Cucu Terkasih" ("Grandfather's Talk to His Lovely Grandchild") and contrasts with the negative yet established images of such women as cruel and evil, as propagated by the New Order (Susanto, 2015:128).

Many stories about ex-Gerwani activists have appeared recently, mostly in the form of non-fiction. The essay collection Suara Perempuan Korban Tragedi '65 (Nadia, 2007) consists of ten memoirs by ex-Gerwani activists and alleged communists who survived the 1965 tragedy. I have included all ten essay titles to showcase the degree of trauma that these women suffered: (1) Ibu Rusminah: "Akhirnya Pemerkosa Itu Jenderal Pensiun"; (2) Ibu Parti: "Perempuan Eks-Tapol Sampah Segala Sampah"; (3) Ibu Yanti: "Membangun Kekuasaan Di atas Kekuasaan"; (4) Ibu Maryanti: "Perempuan Tapol Sasaran Aniaya Moral dan Politik"; (5) Ibu Sukarti: "Ya, PKI Itu Impoten!"; (6) Ibu Sudarsi: "Mengapa Perempuan Harus Punya Vagina dan Payudara"; (7) Ibu Sus: "Membuang Jati Diri Demi Harkat dan Martabat Diri"; (8) Ibu Suparti: "Hidup Saya Dihancurkan karena Suami Saya PKI"; (9) Ibu Badriyah: "Penginjil Orang Miskin"; and (10) Ibu Darmi: "Saya Tinggal Sebatang Jasad." Kidung untuk Korban (Setiawan, ed. 2006) also contains a memoir by an ex-Gerwani leader who survived the tragedy: Paulina Sriningdadi, "Pimpinan Gerwani Cabang Rembang, Diselamatkan Janin di Perut."

Most of these women were jailed without trial. As prisoners, they experienced barbaric and inhumane tortures from electrification to rape. When finally released, they were ostricized by their own families and 
communities and were considered non-human. Their civil rights were stripped away. In short, these punishments sent an important message to Indonesian women: that they should not be involved in any political movement, or else they will be criminalized and jailed. Soon after the rise of the New Order regime, Indonesian women's movements were nearly entirely extinguished.

In Penghancuran Gerakan Perempuan (2010:340), Wieringa states that the most interesting values endorsed by Gerwani activists are independence, hard work, and community service. The organization declares that women must have independence and autonomy in managing their lives. They fight against the traditional Javanese norm that women are merely men's complements. To reach this goal, Gerwani promotes the importance of education to its members. For them, education is not only a basic right for women but also a way to achieve success and agency in the world.

In their official media, Harian Rakyat and Api $K a r t i n i$, the organization encourages members to make reading a habit and promote it among their families. The aim is not only to improve their knowledge of politics (HR 4 Mei 1955), but also to educate their children and cultivate a better, more egalitarian generation (Wieringa, 2010:345). In 1960, for the first time in the history of the organization, it promoted the concept of "pancacinta" (the five loves for children's education): 1) love of nation, 2) love of parents and universal humanism, 3) love of truth and fairness, 4) love of friendship and peace, and love of environment (Wieringa, 2010:347). The militant women's movement in Indonesia challenged the traditional patriarchal worldview, which remains dominant in the nation. Gerwani women, as both politically literate mothers and militant patriots, posed a real threat to the patriarchal status quo. Yet for their idealism, women like Susanto's Ibu paid a cost in the form of life-long suffering.

\section{Moetiah: The Innocent Artist}

Another communist woman who appears in Susanto's story is Moetiah. In "Tak Kau Dengarkah Suara Moetiah?” (“Can't You Hear Moetiah's Voice?”), Susanto introduces Moetiah through a conversation between two 1965 political detainees. It is revealed that the couple plans to join a funeral procession for the reburial of 1965 massacre victims, one of whom is Moetiah. The couple describes Moetiah as a young, multitalented artist. She sang and danced very beuatifully and loved Javanese songs, puppets, and other arts. In a poem, the man of the couple described Moetiah as a sacred yet magical sinden (Javanese traditional singer) (Susanto, 2015:146-148). Although Moetiah died in the 1965 tragedy, people believed that Moetiah's voice could still be heard, especially in the middle of night. Many villagers claimed to have heard her voice many times. As with many other 1965 victims, the story gives no clues as to why Moetiah was killed. Nobody knows. Most likely, of course, she was killed because of her alleged involvement in communist movements. Although we are given few descriptions of Moetiah, it seems clear that she is neither cruel nor inhumane, as the New Order would have us believe.

Similarly positive images of progressive communist artists are also found in some non-fiction books. A collection of 1965 survivors' stories, Kidung untuk Korban (edited by Hersri Setiawan, 2006), includes two narratives by alleged communist artists, Sarbinatun and Bibit. Sarbinatun was a member of Lekra Sala, while Bibit was a dancer of Genjer-genjer. Sarbinatun was a very young woman at that time. She got involved in Lekra because of her father's influence and power as a BTI activist. As a dancer, she often danced at ceremonial events held either by village government, or by PKI and other left organisations. She mastered many kinds of dancing, from national dance to traditional dances. She also performed Genjer-genjer dance while touring from one village to another. In addition to dancing in the villages, she also performed professionally in the biggest theater building in Sala at that time, Sriwedari. In her memoir, "Laki-laki Dimanfaatkan Tenaganya, Perempuan Seluruh-luruhnya" (2006:48), she recalls the audiences' favorite dances, like "Genjer-genjer," "Tari Tani," and "Nandung Jagung." Sometimes she also performed as a comedian. She was very happy at that time, for with her artistic skills, she could bring to her people, especially the poor, happiness and laughter. In 1965, however, she was jailed without trial as a political prisoner for associating with Lekra. Sarbinatun, like her fictional counterpart, Moetiah, devoted her life to contributing to building nation and improving daily life for the poor with the arts they had mastered. They are far from the stereotypical image of the cruel and evil leftist artist propogated by the New Order.

\section{Bapak (Father): The Idealistic Teacher}

Susanto's collection serves, in part, as a way to reconcile with the history of his family. In a conversation with me, Susanto confessed that his experience of being a descendent of communists inspired him to write the collection. He also explained that he and his family knew that their father was killed, but not the location of his grave. Similar details appear in most of Susanto's stories. One story title in particular shows his concern 
for finding his father's grave: "Aku Belum Tahu di Mana Kubur Bapak" ("I Have No Idea where My Father's Tomb Is"). In this story, the narrator asks his mother about the location of his father's grave, but his mother remains "mute." The story ends with him still wishing that he could answer his children's question: where their granfather was buried and when?

In "Tamu dari Masa Lalu" ("A Guest from the Past"), Susanto gives a more detailed description of Bapak, this time from the perspective of his father's colleague, Hendrawan Soekotjo, the guest from the past. One day, Soekotjo, who visits the narrator's house, and from him, the narrator obtains information about his lost father. First, his father was an idealistic teacher. Hendrawan and Bapak were classmates in Sekolah Guru Bawah in Bojonegoro, and having graduated, they worked as teacher in different schools and both joined Persatuan Guru Republik Indonesia (PGRI) Non-Vaksternal, a teachers' association that was widely assumed to be communist affiliate. Although Soekotjo did not mention the reason behind their choice to join this organization, it could be assumed that as Non-Vaksternals, they wanted to have more professional independence. Second, Bapak was a brave family man. He sacrificed his life to save his wife, the narrator's mother. It is clearly stated that he did not let her be killed, believing, as he did, that their children deserved that she survives. As a teacher, a husband, and a father, Bapak is humanized and shown to have positive qualities rarely associated with communists in the official and popular discourses.

Another story about Bapak appears in "Penembang Malam" ("Night Singer"). One day the narrator visits the house of Mbah Dirgo, once Bapak's neighbor, to dig up information about Bapak. Dirgo tells many stories about Bapak, whom he calls by his first name, Ripan. He describes Bapak as a polite man (Susanto, 2015:67). From the first time they met, they shared a comfortable rapport, although Dirgo was older. They also shared the same hobby: Perkutut. He also describes Bapak as a smart person, smart enough to make a very strong and beautiful bird cage, which he gave to Dirgo. Finally, he recalls that Bapak was a good singer and calls him "Penembang Malam" (Night Singer), for he always sang traditional Javanese songs in the middle of the night. His singing brought Dirgo comfort and ease.

In addition to supplying these new details, Dirgo also reinforces the image of Bapak as also a very dedicated teacher. He became jujugan - a person who is considered wise man and capable of giving solutions to any problem that other members of the community might bring to him. According to Drigo, Bapak chose to join PGRI Non-Vaksternal to become a more progressive teacher. This association not only advocated on behalf of teachers, but also promoted progressive education that could lead to the betterment of the nation (Susanto, 2015:73-74). Bapak's reputation as a good father is further underscored as well, and Susanto continues to develop this theme in other stories: in "Akhirnya Om Bandrio Pun Bicara" ("Om Bandrio Opens His Mouth at Last"), for example, the narrator witnesses Bapak being very kind to Ibu. He never treated her rudely and never swore at her (Susanto, 2015:96). These narratives about Bapak, from Soekotjo and Dirgo, directly challenge the images of communists as inhumane propagated by the New Order. It proves that the political detainees, like Bapak and others, were actually ordinary civilians with ordinary professions, hobbies, values, and goals, as well as interest in the betterment of the community at large.

It has been widely acknowledged that at the height of political tension in Indonesia during the 1960s, Indonesia's political social, education, economic, and cultural landscapes were radically altered. In the field of education, the national association of Indonesian teachers (PGRI) broke into two: PGRI-Sujono and PGRI-Subiadinata. In Kidung untuk Korban (Setiawan, ed., 2006), Subandi describes having been a teacher associated with the PGRI, which was accused of being a PKI-affiliate. He taught at an elementary school in Salatiga and, in spite of being teacher, never stopped learning himself. While teaching, he continued to his study in SGA Kristen Salatiga and joined PGRI, the teachers association that accomodates its members' aspirations. In 1964, when the association split, Subandi claims that PGRI-Subiadinata became affiliated with SOKSI (Sentral Organisasi Karyawan Seluruh Indonesia), whereas the faction that he joined, PGRI-Sujono, despite being known as "Non-Vaksternal" (which means "no affiliation"), was accused of being a PKI-affiliate. After the 1965 tragedy, he was arrested and jailed without trial. His narrative echoes similar stories from other ex-PGRI Non-Vaksternal teachers who survived 1965, recorded in Kidung untuk Korban. In fiction and in history, it seems, alleged communist-teachers were routinely jailed and vilified despite having earned reputations as dedicated teachers devoted to enlightening their communities with progressive education.

\section{CONCLUSION}

This paper demonstrates that Penjagal Itu Telah Mati has directly challenged the New Order's discursive representation of communist figures and affiliates, 
portraying them as dedicated mother and activist, innocent artist and idealist teacher. These images discursively challenge images of the 1965 victims as evil and inhumane, as shown in some of the cultural works produced under the New Order, like film Penghianatan, Tohari's Kubah, and others. New historicism theory has enabled us to unpack the link between the collection and the outside world of the author. We can see that there are similarities between characters in Susanto's fiction and in his and others' nonfictional works: most of the victims are portrayed as innocent civilians dedicated to the betterment of their communities, but criminalized and jailed without trial. These images provide an alternative to the narratives about communists and their affiliates officially sanctioned by the New Order. As an example of "Post Suharto 1965 fiction," Susanto's stories have critically challenged the New Order's established historiography.

\section{REFERENCES}

Christanty, Lynda (2015). Fitnah Media Jerman terhadap Perempuan Penulis Indonesia, Literasi.Co., http://literasi.co/fitnah-media-jerman-terhadapperempuan-penulis-indonesia, 2/10/2015.

Chudori, Leila S. (2014). Pulang, Jakarta: Kepustakaan Populer Gramedia.

Geertz, Clifford (1973). "Thick Description: Toward an Interpretive Theory of Culture?" in The Interpretation of Cultures: Selected Essays, New York: Basic Books.

Herlambang, Wijaya (2014). Kekerasan Budaya Pasca 1965, Jakarta: Marjin Kiri.

Heryanto, Ariel (2015). Identitas dan Kenikmatan: Politik Budaya Layar Indonesia, Jakarta: Kepustakaan Populer Gramedia.

Heryanto, A., Mandal, S.K. (2006). State Terrorism and Political Identity in Indonesia: Fatally Belonging, London \& New York: Routledge.

Nadia, Ita F. (2007). Suara Perempuan Korban Tragedi '65, Yogyakarta: Galang Press

Pamuntjak, Laksmi (2013). Amba: Sebuah Novel. Jakarta: Gramedia Pustaka Utama.

Reid, Anthony (2016). Humanities in Indonesia for A Global Age. Humaniora, 28(1), 1-11.

Setiawan, Hersri (2006). Kidung untuk Korban: Dari Tutur Sepuluh Narasusmber Eks-Tapol Sala. Surakarta: Pakorba Sala.

Susanto, Gunawan Budi (2008). Edan-edanan Pada Zaman Edan. Semarang: Cipta Prima Nusantara.

Susanto, Gunawan Budi (2011). Nyanyian Penggali Kubur. Semarang: Gigih Pustaka Mandiri.

Susanto, Gunawan Budi (2015). Penjagal Itu Telah Mati. Blora: Pataba Press.
Susanto, Gunawan Budi (2018). Cik Hwa. Semarang: Cipta Prima Nusantara.

Thaum, Yoseph Yaphi (2013). Representasi Tragedi 1965: Kajian New Historicism atas Teks-Teks Sastra dan Non-Sastra Tahun 1966-1998 (Unpublished doctoral dissertation). Universitas Gadjah Mada, Yogyakarta, Indonesia.

Tohari, Ahmad (2012). Kubah. Jakarta: Gramedia Pustaka Utama.

Wieringa, Saskia E. (2010). Penghancuran Gerakan Perempuan: Politik Seksual di Indonesia Pascakejatuhan PKI. Yogyakarta: Galang Press. 